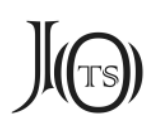

\begin{tabular}{||l||c|c||}
\hline Received 04.07.2020 & JOTS \\
\hline \hline Accepted 13.07.2020 & Review & $5 / 1$ \\
\hline \hline Published 10.01.2021 & & $2021: 212-219$ \\
\hline
\end{tabular}

\title{
Nikolaeva, I. Yukaghir Morphology in a Historical and Comparative Perspective, München: Lincom Europe, 2020, pp. 122, ISBN: 978-3862-900466
}

\author{
Peter PIISPANEN ${ }^{*}$ \\ Stockholm University (Stockholm/Sweden) \\ E-mail: peter.piispanen@finska.su.se
}

During several years of doing Yukaghir studies, I have often wondered about the greater details of Yukaghir morphology, and here is finally the answer. Here we find the evolvement of Nikolaeva's thinking, first through her thesis of 1988, followed by several papers, then through her A historical dictionary of Yukaghir of 2006 and now with the addition of the dimension of Yukaghir historical and comparative morphology in 2020. The volume in question, Yukaghir morphology in a historical and comparative perspective is a hardcover, neat volume with seven chapters and of 122 pages in total. The seven chapters in question are 1. Introduction (p.1-6), 2. The sources and representation of the Yukaghir data (p. 7-11), 3. Nominal morphology (p. 12-50), 4. Pronominals (p. 51-58), 5. Verbal morphology (p. 59-93), 6. Morphology and core syntax (p. 94-108), 7. Final remarks (p. 109-111) and References (p. 112-122). ${ }^{1}$ Clearly, as expected, the majority of the book deals in nominal and verbal morphology in great detail.

Nikolaeva states in the beginning pages (p. 6) one clear and worthwhile goal for this volume:

ORCID ID: 0000-0003-4398-2107.

1 Here I wish to heartfully thank LINCOM Europe, as well as Erdem Uçar, for helping arrange a review copy of this volume, without which this review would not at all have been possible. Also, in the cases where I in this review have suggested some additional comparisons of apparent relevance, I apologize if they were indeed mentioned somewhere, and I had missed them in the original read through. 


\section{J(৫)}

"Indeed, the grammar of Yukaghir has long been thought of as somewhat 'exotic' from the Ural-Altaic point of view. Rédei's (1999) position is typical in this respect. According to him, the Uralo-Yukaghir morphological commonalities do not allow a genetic interpretation essentially because the grammatical structures of Yukaghir, on the one hand, and the Uralic languages, on the other hand, are just too different. He writes (my translation from German): 'the Uralic and Yukaghir conjugations are such dramatically different systems that genetically they cannot have anything to do with each other' (Rédei, 1999: 14-15). One of my major aims in the present work is to prove such statements wrong."

Her intent is thus not to here demonstrate any genetic language relationship, but rather to present details, corrections and data for making future judgements possible. ${ }^{2}$ Many different fascinating and illustrative comparisons are made throughout the volume. Indeed, while making any comparison, matters are presented in an objective and fairly dry academic manner, and no conclusion is very subjective or drawn too far.

Recent research is slowly starting to open up the field of common UraloYukaghir morphology, which is of utmost importance - providing important cornerstones for the question of the validity or non-validity of the UraloYukaghir genetic relationship. In addition to the volume under introspection by Nikoleava, another work of interest is Merlijn De Smit's (thus far unpublished) paper Reconsidering Uralo-Yukaghir morphology, which has numerous new insights strongly suggesting the validity (my own conclusion) of a genetic interpretation of the Uralo-Yukaghir relationship based in a morphological point of view. Any reader of Nikolaeva's new volume is advised to also collect further materials from De Smit's paper.

Chapter 2, named The sources and representation of the Yukaghir data, deals well with the bibliographic listing of lexical and grammatical data. Important details regarding prosody and morphological behaviour and root structure are given here, which is required for better following the argumentation of the book.

The chapter (3) on Nominal morphology presents how nouns are inflected with number, possessive agreement and case, in that order. This chapter is

2 Still, it should be very evident from Nikolaeva's assorted works, as well as the way she phrases conclusions and analyses, that she does believe in an Uralo-Yukaghir affinity, as does the present author. Even eminent Uralist Juha Janhunen admitted (2009: 61) that such an affinity is possible, but that it may be so archaic that the traces and connections have been obscured by now. 


\section{J(৫)}

perhaps the most important one in the full volume. For example, it appears that there existed a collective plural marker $\left({ }^{*}-p\right.$, which became -pul in Tundra Yukaghir). of particular interest is, of course, the grammatical case markers (starting on p. 15). ${ }^{3}$ Nikolaeva provides a believable picture of the likely historical development of said case markers (for example: p. 21). Noteworthy and probably of interest for every comparative linguist reading this volume - are the external comparisons with other surrounding Siberian languages, and therewith we benefit from new arguments strengthening or weakening the conclusions of older research (in particularly countering some of Kurilov's, Rédei's (1999) and Aikio's (2014) argumentation, and the tentative conclusions basically agree with much of the Yukaghir research done by Collinder, Angere, Tailleur, Krejnovič, Harms, Fortescue and Piispanen). Indeed, very strong correlation is to be found between the Yukaghir and the Uralic case markers. In particular the Yukaghir-Samoyedic comparisons (PY \& PS, respective protolanguage) are utterly striking and worthy of note (p. 29-33, 35, 47). ${ }^{4}$

According to this author, extreme similarities of the above kind can hardly be dismissed as being coincidental, or due to areal contacts, but rather as direct proof of a genetic language relationship (particularly as there are also in excess of two hundred reasonable cognate suggestions to be found, much within the basic vocabulary, pronominal systems and numerals); it is clear from the presentation and argumentation that Nikolaeva also follows this line of thinking (eg. p. 49-50).

\footnotetext{
In short, the Yukaghir ( $\mathrm{KY}=\mathrm{Kolyma}, \mathrm{TY}=\mathrm{Tundra}$ ) grammatical case markers are: nominative ( $\mathrm{KY}$ and TY - $\varnothing$ ), accusative (KY -gələ/-kələ, TY - -əənə/-qənə), partitive (KY - ; TY -lo), instrumental (KY -lo, TY $-l e k)$, genitive (KY and TY $-n /-d)$, dative (KY $-(\eta i) n, T Y-(\eta i) n ́)$, locative (KY $-g \partial /-k \partial$, TY $\left.-\gamma^{\prime} /-q \partial\right)$, ablative (KY -gat/-kat, TY - -əət/-qət), prolative (KY -gən/-kən, TY - -əən/-qən), subject comitative (KY

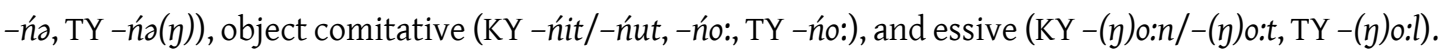
As the presentation goes on, Nikolaeva also convincingly reconstructs what the common Late ProtoYukaghir grammatical case markers should have looked like.

4 PS *-nä 'companion, sibling' <> PY * -ńə 'reciprocal/proprietive stem'; Genitive: PS *-n $<>$ PY *-n; Lative: PS *-n <> PY *-ni; Locative: PS *-kâ-nå/*-kâ-nä <> PY *-kə(nə); Ablative: PS *-kâ-tâ <> PY *_ kat ( $\left.<^{*}-\mathrm{yket}\right)$; Dual: PU ${ }^{*}-\mathrm{k}(\mathrm{v})<>\mathrm{PY}{ }^{*} k \mathrm{k}^{-}$'two'. Here I would personally like to add the following comparisons to be gleaned and summarized from throughout the text and other sources: Comitative: Finnish -ne (+pos. suffix -en); Vach and Vasjugan Khanty -näat, -nāt, Tavda Mansi -nät, -nāt <> KY -ne, -ńit, -ńut, TY -ńen; Adverbial locative: PS *-na/*-nä <> PY *-nə; Adverbial lative: PS *-ntə <> PY *_ jinta. Furthermore, both Finnish and Yukaghir have - $k$ imperatives (Harms, 1977: 311).
} 


\section{J(৫)}

In chapter 4 we find Pronominals (p. 51-58). Yukaghir pronominals are mostly monosyllabic, and many of them have direct Uralic counterparts (p. 54), as well as, perhaps surprisingly, a few Altaic counterparts; examples include the interrogative PY *qa-/*qo- PU *ku-/*ko- (Rédei, 1988-1991: 191-192), and PY *ki-n 'who' PU *ken 'who' (Rédei, 1988-1991: 140-141) Altaic *k'a(j) 'who' (Starostin et al., 2003: 754). Similarities abound also in all the personal pronouns, which is difficult to explain other than as part of a common origin; Nikolaeva ponders on the question if the "Uralic, Altaic and Yukaghir pronominal stems may ultimately be related on a deeper macro-genetic level” (p. 58).

In chapter 5, Verbal morphology (p. 59-93), we obtain a clear view of the inflectional categories of not only the Yukaghir languages, but also of Uralic and Altaic languages in comparison. Differing slightly from previous researchers, Nikolaeva suggests two classes of inflectional moods, depending on their morphological expressions; the first class consists of indicative, irrealis, prospective, evidential, desiderative and debitive, and many markers are believed to have developed quite recently. As for tense, unmarked aorist and inflectional future are given. Further, subject agreement, converbs, and particles are treated in detail with numerous comparisons. ${ }^{5}$

Naturally, there are several morphological parallels between Uralic and Yukaghir, perhaps the most interesting: a. $\mathrm{PU}{ }^{*}{ }_{-} \mathrm{mA}^{-}$; nominal derivational suffix (Aikio, 2002: 34-35); PS *-ma ${ }^{*}-$ me $<$ PY *-mə - ; nominal derivational suffix (Nikolaeva, 2006: 81); b. PU *-jA 'suffix of active particles, and nomina agentis derived from verbal stems' $>\mathrm{PY}{ }^{*}$-ja 'imperfective particle'; c. PU *-w'passive, stative or reflexive verbal suffix' $<P \mathrm{PY}^{*}{ }_{-}^{-\mathrm{uw}{ }^{*}-\partial \mathrm{w}}$ 'passive or stative suffix of intransitive verbs'; d. PU *-tA 'transitive suffix' $<>$ PY *-t(ə) 'transitive suffix'; e. PU *-nt(V) 'intransitive/multiplicative/iterative/imperfective suffix' <> PY *-ntə 'detransitivizer suffix'; f. PU * $-\mathrm{m}(\mathrm{V})$ 'inchoative suffix' $<>\mathrm{PY}^{*}{ }_{-}$mu

5 Nikolaeva also corrects my own mistake (in a footnote on p. 83) that the nominal suffix -ja was hitherto non-described in literature (Piispanen, 2020: 153-156), whereas it has been quite extensively described in different and similar terms by both Krejnovic (for Tundra Yukaghir) and Maslova (for Kolyma Yukaghir). 
'inchoative suffix'. ${ }^{6}$ While the above are quite striking, Nikolaeva also mentions the differences in morphology, and some possible reasons for it.

In chapter 6, Morphology and core syntax (p. 94-108), the personal pronouns and verbal morphology by persona and numerus, among other matters, are discussed. Again, there are strong similarities between Yukaghir and Uralic, and, in some cases also to the Altaic languages. It is concluded that the genetic language affinities may be implied by these monosyllabic stems.

And finally in chapter 7, Final remarks (p. 109-111), briefly summarizes the major findings of this volume. In the concluding words (p. 109), Nikolaeva states that she hopefully has demonstrated that the core grammatical structure of Yukaghir is not particularly unusual if measured towards an Uralic and Altaic background before language-particular processes obscured the parallellisms. Typologically speaking, Yukaghir is similar to the Uralic and Altaic languages. Like Janhunen $(2009,2014)$ stated, Yukaghir aligns typologically with the UralAltaic 'linguistic belt'. Certain properties are shared only between Yukaghir and the Samoyedic languages (and some also with Eastern Uralic in general). The main typological differences are found in the coding of core grammatical arguments, differences which have resulted from quite late changes in the Yukaghir languages. The similarities, on the other hand, cannot all be due to language contacts, because these specific features are missing from the intervening Tungusic languages. Significantly, there are many morphological parallels between Uralic and Yukaghir, which, Nikolaeva states, are also found within numerous previously suggested cognates. In summary, Nikolaeva suggests that all parallels can be interpreted in three different ways: 1 . They can be treated as chance resemblances, 2 . They are the result of language contact, or

\footnotetext{
6 Two convincing Yukaghir-Altaic parallel are also given (p. 90). However, I would like to add the following comparisons to this comparative body of work, suggesting tentative cognancy: PU *-(i)nti'frequentative verbal suffix' (Aikio, 2014: 90) <> PY *-ńčə- > KY -žə -žu 'the only known frequentative verbal suffix' (Nikolaeva, 2006: 80); PU *-śä- 'nominal derivational suffix' (Aikio, 2002: 23-24). Example: PU *ńimi- 'to suck' > PU *ním-śä 'breast, teat' > PS *nimse 'breast, milk' > Selkup ńipsa 'breast, milk' $>$ PY *-sə- (actually: *-śə-) 'nominal derivational suffix, a hypothetical suffix according to common personal observations'. Example: KY ibiši: 'woman's breast; nipple; milk' (*iw-śz- < PY *iw'to suck' < Pre-PU *(ń)imi- 'to suck'), likely through *-śä- > *-śa > *-śə-: and, finally, PS *-jâ- 'nominal derivative suffix' <> PY*-i: > KY \& TY -i: 'nominal derivative suffix' (Nikolaeva, 2006: 80).
} 


\section{J(৫)}

3. They are the result of a genetic inheritance deriving from a common ProtoUralo-Yukaghir stage.

While the purpose of neither this review nor the book being reviewed is to prove the Uralo-Yukaghir affinity, let us still dwell a bit further on option 3, that is that there existed a valid Uralo-Yukaghir language stage. Nikolaeva agreeably suggests that, if valid, such a common tentative stage must have existed far before 5000 BP, because the Uralic languages themselves are believed to be from around 5000 BP. Based on my own interpretation of the depth of historical processes in the two language groups, I would personally suggest that the common Uralo-Yukaghir relationship existed somewhere in the ballpark of 6000-8000 BP. She further notes that the tentative Uralo-Yukaghir cognates - far from all being published yet ${ }^{7}$ - often pertain to basic vocabulary, core grammar, some cases, inherent and contextual inflection, and these likely do not represent borrowings. She further suggests that etymological support is required to prove the thesis (albeit she also wisely notes that no amount of data will ever convince those who do not believe in this long-range relationship in the first place; the same is completely true also of the Altaic genetic language hypothesis). Indeed, according to this reviewer, the existence of an early Uralo-Yukaghir language stage is the only reasonable explanation regarding the cumulative results found in the current state-of-the-art comparative Uralo-Yukaghir linguistics; Nikolaeva's book will no doubt aid in such future research enterprises, providing the brunt of morphological evidence.

Furthermore, Nikolaeva states that the Uralo-Yukaghir genetic hypothesis has gained some popularity in recent years. The reason for this is that more lexical correspondences between the two language groups have been noted and suggested (but, it must be told, there are also exists a very notable number of additional cognates to discussed which have not yet been published - at least over 200 reasonably good correspondences (i.e. suggested cognates) in total

\footnotetext{
Here I might mention to the interested reader that a small group of researchers is currently working diligently on a new compilation with the goal to prove the existence of the Uralo-Yukaghir genetic language relationship, with particular focus on lexical studies (perhaps this broad and decisive goal well mirrors the stated intent in Starostin et al., 2003, which dealt with the Altaic languages, but which sadly failed to convince for a number of methodological reasons); the volume will be quite thick and hopefully comprehensively summarize many decades of research and with much new data.
} 
exist). Furthermore, three new actual sound laws showing the development from Proto-Uralo-Yukaghir have been suggested (Piispanen, 2013, 2015 \& 2016), and now with De Smit and Nikolaeva's new volume we also have solid morphological comparisons. In this book, Nikolaeva states a great conclusion and edict: "Nevertheless, the relevant Uralo-Yukaghir comparative material is not a matter of a single isolated parallel; it provides a weight of cumulative evidence" (Nikolaeva, 2020: 111).

In conclusion, this volume is indispensable both for understanding Yukaghir historical grammatical processes and the typology of the language, as well as for putting the language family into the context of the Uralic and Altaic languages. It goes well in hand with other important works on Yukaghir grammar, including Maslova (2003; on Kolyma Yukaghir). It offers many new insights, comparisons, and reconstructions, and will prove important for future comparative studies.

\section{Abbreviations}

$$
\begin{aligned}
& \mathrm{KY}=\text { Kolyma Yukaghir } \\
& \mathrm{PS}=\text { Proto-Samoyed } \\
& \mathrm{PU}=\text { Proto-Uralic } \\
& \mathrm{PY}=\text { Late Proto-Yukaghir } \\
& \text { TY = Tundra Yukaghir }
\end{aligned}
$$

\section{References}

Aikio, A. (2002). New and Old Samoyed Etymologies. Finnisch-Ugrische Forschungen, 57, 9-57.

Aikio, A. (2014). The Uralic-Yukaghir lexical correspondences: genetic inheritance, language contact or chance resemblance? Finnisch-Ugrische Forschungen, 62, 7-76.

De Smit, M. (2019). Reconsidering Uralo-Yukaghir morphology. [Unpublished draft paper].

Harms, R. D. (1977). The Uralo-Yukaghir focus system: A problem in remote genetic relationship. In Hopper, P. J. (Ed.), Studies in Descriptive and Historical Linguistics (p. 301-316). John Benjamins Publishing Company. 


\section{1(0)}

Janhunen, J. (2009). Proto-Uralic - what, where and when? In Ylikoski, J. (Ed.), The quasquicentennial of the Finno-Ugric Society (p. 57-78). Suomalais-Ugrilainen Seura.

Janhunen, J. (2014). Ural-Altaic: The polygenetic origins of nominal morphology in the Transeurasian zone. In Robbeets, M. \& Bisang, W. (Eds.), Paradigm change in the Transeurasian languages and beyond (p. 311-336). John Benjamins Publishing Company.

Maslova, E. (2003). A Grammar of Kolyma Yukaghir. Mouton de Gruyter.

Nikolaeva, I. (1988). Problema uralo-jukagirskix genetičeskix svjazej [The problem of the Uralo-Yukaghir genetic relationship]. The Institute of Linguistics, Russian Academy of Sciences. Moskow. [Unpublished PhD. Diss.]

Nikolaeva, I. (2006). A historical dictionary of Yukaghir. Mouton de Gruyter.

Nikolaeva, I. (2020). Yukaghir morphology in a historical and comparative perspective. LINCOM Europe.

Piispanen, P. S. (2013). The Uralic-Yukaghiric connection revisited: Sound Correspondence of Geminate Clusters. Finnisch-Ugrische Forschungen, 94, 165-197.

Piispanen, P. S. (2015). Evaluating the Uralic-Yukaghiric word-initial, protosibilant correspondence rules. Finnisch-Ugrische Forschungen, 95, 237-273.

Piispanen, P. S. (2016). A prosody-controlled semi-vowel alternation in Yukaghir. Journal of Historical Linguistics, 6(2), 247-296.

Piispanen, P. S. (2020). Additional Turkic and Tungusic Borrowings into Yukaghir IV. Journal of Old Turkic Studies, 4(1), 152-187.

Rédei, K. (1988-1991). Uralisches etymologisches Wörterbuch. Akadémiai Kiadó.

Rédei, K. (1999). Zu den uralisch-jukagirischen Sprachkontakten. Finnisch-Ugrische Forschungen, 55, 1-58.

Starostin, S. et al. (2003). An etymological dictionary of Altaic languages I-III. Brill. 